Crosbie, R. B. (1963). British Medical fournal, 1, 788.

Curtis, J. R., et al. (1969). Quarterly fournal of Medicine, 38, 49.

Edward, N., Young, D. P. G., and MacLeod, M. (1964). Fournal of Clinical Pathology, 17, 365 .

Evans, R. J., and Waterworth, P. M. (1966). Fournal of Clinical Patho$\log y, 19,555$.

Fletcher, A. P., Alkjaersig, N., and Sherry, S. (1959). fournal of Clinical Investigation, 38, 1096.

Kopp, K. F., Grossmann, D. F., and Frey, J. (1967). In Dialysis and Transplantation: Proceedings of the 4th Conference of the European Dialysis and Transplant Association, edited by D. N. S. Kerr, p. 373. Amsterdam, Excerpta Medica.

MacLeod, M., Stalker, A. L., and Ogston, D. (1962). Lancet, 1, 191.
Martin, A. M., Clunie, G. J. A., Tonkin, R. W., and Robson, J. S. (1967). In Dialysis and Transplantation: Proceedings of the 4th Conference of the European Dialysis and Transplant Association, edited by D. N. S. Kerr, p. 67. Amsterdam, Excerpta Medica.

Moser, K. M., and Hajiar, G. C. (1967). Annals of Internal Medicine, 66, 1207.

Pendras, J. P., and Smith, M. P. (1966). Transactions of the American Society for Artificial Internal Organs, 12, 222.

Ramirez, O., Swartz, C., Onesti, G., Mailloux, L., and Brest, A. N. (1966). Transactions of the American Society for Artificial Internal Organs, 12, 220.

Taylor, G., and Bloor, K. (1962). Lancet, 1, 935.

Wing, A. J., Curtio, J. R., and de Wardener, H. E. (1967). British Medical fournal, 3, 143 .

\title{
Comparison of Depot Tetracosactrin and Corticotrophin Gel
}

\author{
B. L. J. TREADWELL,* M.B., M.R.A.C.P., M.R.C.P.ED.; P. M. DENNIS, $\dagger$ M.B., F.R.A.C.P., M.R.C.PATH.
}

British Medical fournal, 1969, 4, 720-723

Cummary : Depot tetracosactrin has been compared with $\checkmark$ corticotrophin gel in 12 inpatients of a rheumatic diseases unit. Every patient received one subcutaneous injection each of the synthetic and the animal preparation, with serial measurements of plasma 11-hydroxycorticosteroids, 12-hourly urinary 11-hydroxycorticosteroids, and 17-oxogenic steroids. The duration of action of the depot tetracosactrin was virtually twice that of corticotrophin gel, the dose relationship being about $0.25 \mathrm{mg}$. of depot tetracosactrin to 50 units of gel. Local reaction to the injection of depot tetracosactrin was relatively frequent.

\section{Introduction}

The first report of synthetic polypeptides with corticotrophinreleasing activity came from Kappeler and Schwyzer (1960). Subsequently these authors (1961) described the preparation of a synthetic polypeptide (Synacthen) in crystalline form which was highly soluble in water and rapidly absorbed after intramuscular injection. Landon et al. (1964) showed that infused Synacthen (tetracosactrin) increased both plasma cortisol levels and urinary 17-ketosteroids and 17-hydroxycorticosteroids (17-OHCS). The synthetic preparation caused no sensitivity reaction in two patients sensitive to animal corticotrophin. Tetracosactrin consists of the first 24 amino-acids found in the 39 amino-acid chain of animal corticotrophin. It has a high degree of activity lasting one and a half to three hours by intramuscular injection. Since 19.67 a long-acting preparation of

* Rheumatologist, Wellington Hospital, Wellington, New Zealand.

† Chemical Pathologist, Prince Henry's Hospital, Melbourne, Victoria, Australia. tetracosactrin adsorbed on to an inorganic zinc complex has been on trial. Besser et al. (1967) and Nelson et al. (1968) reported the effect of depot tetracosactrin on plasma 11-hydroxycorticosteroids (11-OHCS). We describe here our experience of this substance with both plasma and urinary steroids as criteria, our aim being to assess biochemical and clinical effects in comparison with corticotrophin gel.

\section{Patients and Methods}

There were 12 subjects, 11 with rheumatoid disease and 1 with gout. All were hospital inpatients with clinical disease activity, so that therapeutic observations were possible. No patient had ever previously been treated with corticosteroids or corticotrophin. In every case the proposed investigation was fully explained to the patients, their approval to proceed being obtained. Administration of depot tetracosactrin and corticotrophin gel was subcutaneously, as this is the only feasible route for self-administration should long-term therapy be required.

Studies in each case covered six days with 12-hourly urine collections from 9 a.m. to 9 p.m. and from 9 p.m. to 9 a.m. throughout. Corticotrophin was administered at 9 a.m. on Day 2 and Day 5, every patient receiving one dose of depot tetracosactrin and one dose of corticotrophin gel. During the course of the trial three dose levels of tetracosactrin were used: $1,0.5$, and $0.25 \mathrm{mg}$. Corticotrophin gel was assessed at twodose levels: 50 and 25 units. Half the patients received tetracosactrin on Day 2 and corticotrophin gel on Day 5. The remaining patients received their injections in the reverse order. Plasma 11-OHCS (Mattingly, 1962) were determined in each

TABBLE I.-Plasma 11-OHCS Expressed as $\mu g . / 100 \mathrm{ml}$. Related to Time of Day. Corticotrophin (A.C.T.H.) was Administered at 9 a.m. on Day 2 and Day 5

\begin{tabular}{|c|c|c|c|c|c|c|c|c|c|c|c|c|c|c|c|c|c|c|}
\hline \multirow{3}{*}{$\begin{array}{l}\text { Case } \\
\text { No. }\end{array}$} & \multirow{3}{*}{ Age } & \multirow{3}{*}{ Sex } & \multirow{3}{*}{$\begin{array}{l}\text { Day } 1 \\
9 \text { a.m. }\end{array}$} & \multicolumn{6}{|c|}{ Day 2} & \multirow{3}{*}{$\begin{array}{l}\text { Day } 3 \\
9 \text { a.m. }\end{array}$} & \multirow{3}{*}{$\begin{array}{l}\text { Day } 4 \\
9 \text { a.m. }\end{array}$} & \multicolumn{6}{|c|}{ Day 5} & \multirow{3}{*}{$\begin{array}{l}\text { Day } 6 \\
9 \text { a.m. }\end{array}$} \\
\hline & & & & \multicolumn{2}{|c|}{ A.C.T.H. } & \multirow{2}{*}{9 a.m. } & \multirow{2}{*}{1 p.m. } & \multirow{2}{*}{5 p.m. } & \multirow{2}{*}{9 p.m. } & & & \multicolumn{2}{|c|}{ A.C.T.H. } & \multirow{2}{*}{9 a.m. } & \multirow{2}{*}{1 p.m. } & \multirow{2}{*}{5 p.m. } & \multirow{2}{*}{9 p.m. } & \\
\hline & & & & Type & Dose & & & & & & & Type & Dose & & & & & \\
\hline $\begin{array}{r}1 \\
2 \\
3 \\
4 \\
5 \\
6 \\
7 \\
8 \\
9 \\
10 \\
11 \\
12\end{array}$ & \begin{tabular}{|l|}
56 \\
68 \\
45 \\
54 \\
50 \\
52 \\
61 \\
68 \\
54 \\
60 \\
76 \\
50
\end{tabular} & $\begin{array}{c}M \\
\mathbf{F} \\
\mathbf{M} \\
\mathbf{M} \\
\mathbf{F} \\
\mathbf{F} \\
\mathbf{F} \\
\mathbf{F} \\
\mathbf{F} \\
\mathbf{M} \\
\mathbf{M}\end{array}$ & $\begin{array}{l}16 \\
19 \\
17 \cdot 5 \\
6.5 \\
9.5 \\
15 \\
7 \\
2 \\
7 \\
17.5 \\
21.5 \\
21\end{array}$ & $\begin{array}{l}\text { TCA } \\
\text { TCA } \\
\text { TCA } \\
\text { TCA } \\
\text { TCA } \\
\text { TCA } \\
\text { Gel } \\
\text { Gel } \\
\text { Gel } \\
\text { Gel } \\
\text { Gel } \\
\text { Gel }\end{array}$ & \begin{tabular}{|c|}
$1 \mathrm{mg}$. \\
$1 \mathrm{mg}$ \\
$0.5 \mathrm{mg}$. \\
$0.5 \mathrm{mg}$. \\
$0.25 \mathrm{mg}$. \\
$0.25 \mathrm{mg}$. \\
25 units \\
50 units \\
25 units \\
50 units \\
25 units \\
50 units
\end{tabular} & $\begin{array}{c}18 \\
20 \\
18 \\
6 \\
31 \\
19 \cdot 5 \\
17 \cdot 5 \\
2 \\
9 \\
23 \cdot 5 \\
13 \\
27\end{array}$ & $\begin{array}{l}76 \cdot 8 \\
72 \\
38 \cdot 5 \\
78 \\
59 \\
55 \\
77 \cdot 5 \\
55 \cdot 5 \\
70 \\
63 \\
50 \\
66 \cdot 5\end{array}$ & $\begin{array}{l}36 \\
95 \\
59 \cdot 5 \\
87 \\
62 \\
56 \\
85 \\
71 \\
40 \cdot 5 \\
79 \\
49 \\
40\end{array}$ & $\begin{array}{l}32 \cdot 5 \\
51 \\
89 \\
44 \cdot 5 \\
65 \\
67 \\
44 \cdot 5 \\
21 \cdot 5 \\
47 \\
32 \\
33 \cdot 5\end{array}$ & $\begin{array}{c}64 \\
64 \\
47 \\
90 \\
41 \\
54 \\
16 \\
2 \\
2 \\
14 \\
7 \cdot 5 \\
20\end{array}$ & $\begin{array}{c}53 \cdot 3 \\
9 \\
15 \\
24 \\
33 \\
20 \\
20 \\
8 \\
2 \\
26 \cdot 5 \\
24 \\
37\end{array}$ & $\begin{array}{l}\text { Gel } \\
\text { Gel } \\
\text { Gel } \\
\text { Gel } \\
\text { Gel } \\
\text { Gel } \\
\text { TCA } \\
\text { TCA } \\
\text { TCA } \\
\text { TCA } \\
\text { TCA } \\
\text { TCA }\end{array}$ & $\begin{array}{l}25 \text { units } \\
50 \text { units } \\
25 \text { units } \\
50 \text { units } \\
25 \text { units } \\
50 \text { units } \\
1 \mathrm{mg} . \\
1 \mathrm{mg} . \\
0.5 \mathrm{mg} . \\
0.5 \mathrm{mg} . \\
0.25 \mathrm{mg} . \\
0.25 \mathrm{mg} .\end{array}$ & $\begin{array}{l}16 \\
14 \\
19 \\
35 \\
37 \\
35 \\
26 \\
20 \\
2 \\
18 \cdot 5 \\
14 \\
31\end{array}$ & $\begin{array}{l}57 \\
41 \cdot 3 \\
44 \cdot 5 \\
71 \\
45 \\
52 \cdot 5 \\
96 \\
36 \\
43 \\
62 \\
70 \\
55\end{array}$ & $\begin{array}{l}66 \cdot 5 \\
44 \cdot 5 \\
34 \\
55 \\
47 \\
48 \\
93 \\
64 \\
45 \\
75 \\
81 \\
48\end{array}$ & $\begin{array}{c}35 \cdot 5 \\
28 \\
12 \\
53 \\
32 \\
20 \\
133 \\
52 \\
54 \\
67 \\
69 \\
81\end{array}$ & $\begin{array}{c}59 \cdot 5 \\
20 \cdot 5 \\
10 \\
25 \\
2 \\
120 \\
55 \\
49 \\
68 \cdot 5 \\
34 \\
49\end{array}$ \\
\hline
\end{tabular}

$\mathrm{TCA}=$ Depot tetracosactrin. $\mathrm{Gel}=$ Corticotrophin gel. 
case at 9 a.m. on Days 1, 3, 4, and 6, and at 9 a.m., 1 p.m., 5 p.m., and 9 p.m. on Days 2 and 5. The 12-hour urinary excretion of 11-OHCS (Mattingly et al., 1964) and 17-oxo- and 17-oxogenic steroids (17-OGS) (Appleby et al., 1955) was also measured.

\section{Results}

\section{Biochemical Observations}

The findings in Case 6 are depicted (Fig. 1) illustrating the form of each case study. Neither plasma nor urinary steroid measurements showed any significant or consistent advantage attached to the order of administration, whether it be the first or the second injection. It is not proposed, therefore, to consider this aspect further.

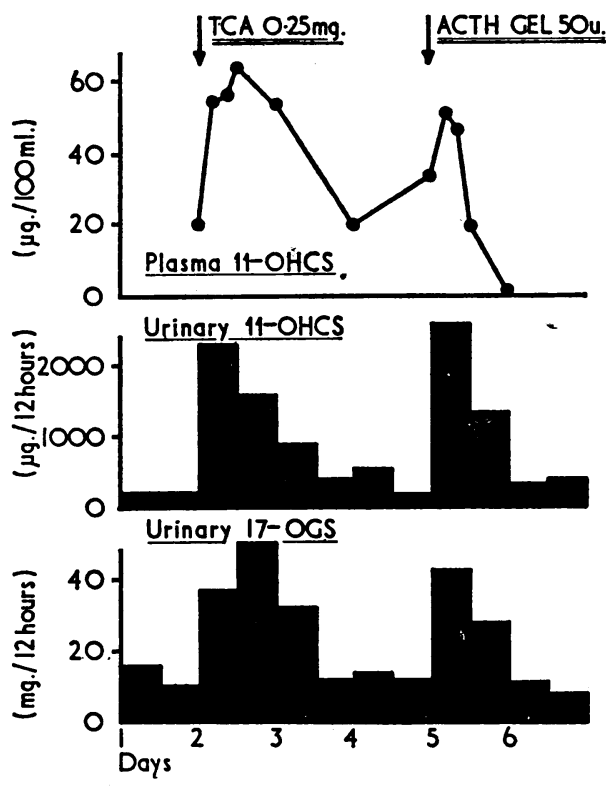

FIG. 1.-Case 6. Findings illustrating the time relationship between corticotrophin (A.C.T.H.) injections, blood samples, and urine collections. Each day starts at 9 a.m. TCA $=$ tetracosactrin depot.

As three dose levels of depot tetracosactrin and two dose levels of corticotrophin gel were used it is apparent that four patients had the same dose of the synthetic preparation and six patients the same dose of corticotrophin gel. Table I records the details of plasma 11-OHCS in each case studied, together with the age and sex, and the type and dosage of corticotrophin. Individual 12-hour urinary 11-OHCS findings are given in Table II. When the mean plasma 11-OHCS levels for each dose are calculated (Fig. 2), it can be seen that following corticotrophin gel the levels of these steroids fall rapidly towards the baseline after 12 hours, reaching basal values in
24 hours after 25 units, and have almost reached baseline in 24 hours after 50 units. Plasma 11-OHCS levels, however, remain high 24 hours after the injection of the synthetic preparation in a dose as low as $0.25 \mathrm{mg}$., and may still be a little raised after 48 hours, at least with a dose of $1 \mathrm{mg}$.

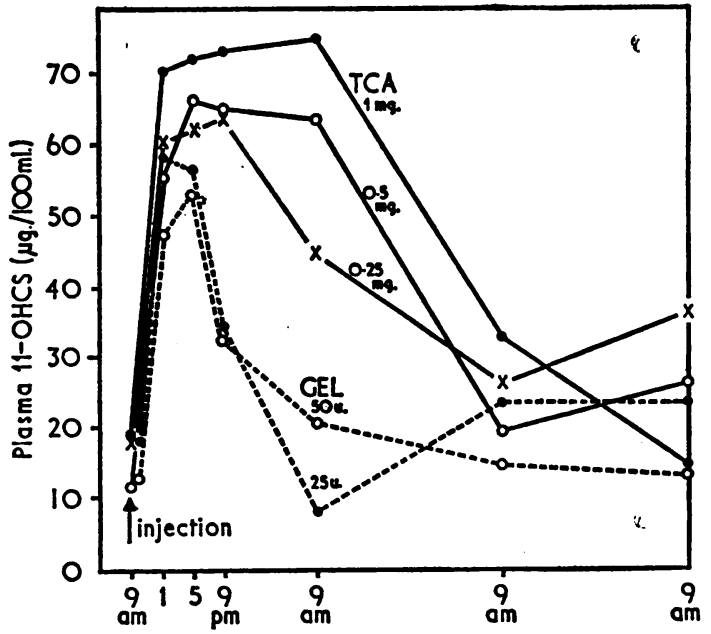

Fig. 2.-Mean plasma 11-OHCS at each dose level of depot tetracosactrin (TCA) and corticotrophin gel (GEL) on a time scale of 72 hours.

It is apparent from the mean urinary 11-OHCS (Fig. 3) that following $1 \mathrm{mg}$. of depot tetracosactrin the 11-OHCS response increases to a maximum at 24 to 36 hours, during which period the output is nine times that following 50 units of corticotrophin gel. If no allowance is made for individual baseline variation, the output of $11-\mathrm{OHCS}$ following $0.25 \mathrm{mg}$. of depot tetracosactrin is similar to that following the injection
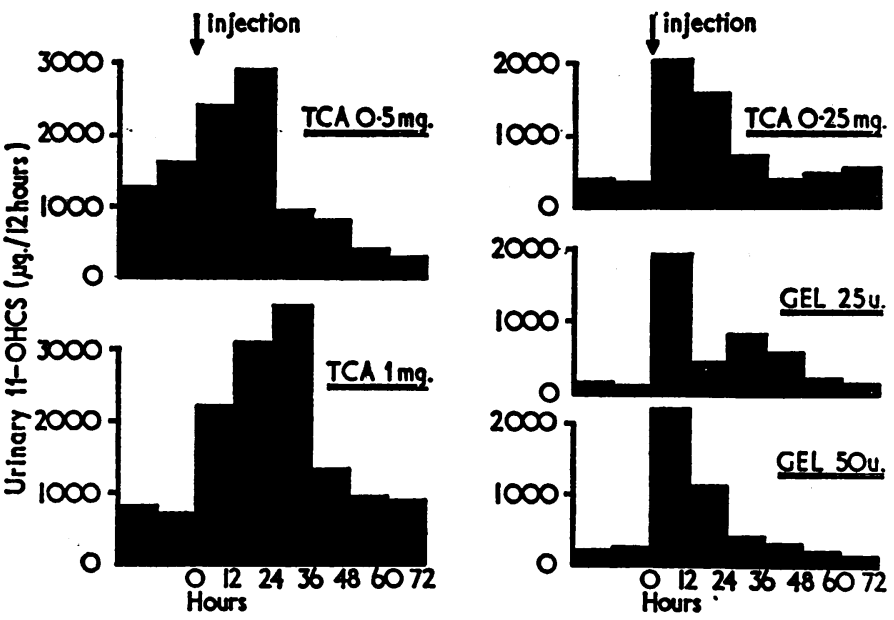

FIG. 3.-Mean urinary 11-OHCS ( $\mu$ g./12 hours) following depot tetra cosactrin (TCA) at three dose levels, and corticotrophin gel (GEL) at two dose levels.

TABle II.-Urinary 11-OHCS Expressed as $\mu g . / 12$ Hours for Both Collection Periods of All Six Days in Every Patient Assessed. Corticotrophin was Administered at 9 a.m. on Day 2 and Day 5

\begin{tabular}{|c|c|c|c|c|c|c|c|c|c|c|c|c|}
\hline \multirow{2}{*}{$\begin{array}{l}\text { Case } \\
\text { No. }\end{array}$} & \multicolumn{2}{|c|}{ Day 1} & \multicolumn{2}{|c|}{ Day 2} & \multicolumn{2}{|c|}{ Day 3} & \multicolumn{2}{|c|}{ Day 4} & \multicolumn{2}{|c|}{ Day 5} & \multicolumn{2}{|c|}{ Day 6} \\
\hline & $\begin{array}{l}9 \text { a.m.- } \\
9 \text { p.m. }\end{array}$ & $\begin{array}{l}9 \text { p.m.- } \\
9 \text { a.m. }\end{array}$ & $\begin{array}{l}9 \text { a.m.- } \\
9 \text { p.m. }\end{array}$ & $\begin{array}{l}9 \text { p.m.- } \\
9 \text { a.m. }\end{array}$ & $\begin{array}{l}9 \text { a.m.- } \\
9 \text { p.m. }\end{array}$ & $\begin{array}{l}9 \text { p.m.- } \\
9 \text { a.m. }\end{array}$ & $\begin{array}{l}9 \text { a.m.- } \\
9 \text { p.m. }\end{array}$ & $\begin{array}{l}9 \text { p.m- } \\
9 \text { a.m. }\end{array}$ & $\begin{array}{l}9 \text { a.m.- } \\
9 \text { p.m. }\end{array}$ & $\begin{array}{l}9 \text { p.m.- } \\
9 \text { a.m. }\end{array}$ & $\begin{array}{l}9 \text { a.m.- } \\
9 \text { p.m. }\end{array}$ & $\begin{array}{l}9 \text { p.m.- } \\
9 \text { a.m. }\end{array}$ \\
\hline $\begin{array}{r}1 \\
2 \\
3 \\
4 \\
5 \\
6 \\
7 \\
8 \\
9 \\
10 \\
11 \\
12\end{array}$ & $\begin{array}{r}1,345 \\
275 \\
385 \\
1,960 \\
388 \\
258 \\
77 \\
198 \\
354 \\
173 \\
100 \\
280\end{array}$ & $\begin{array}{r}742 \\
625 \\
335 \\
2,850 \\
380 \\
258 \\
124 \\
198 \\
285 \\
101 \\
41 \\
372\end{array}$ & $\begin{array}{r}3,290 \\
1,170 \\
2,210 \\
3,900 \\
2,150 \\
2,400 \\
1,320 \\
147 \\
1,335 \\
910 \\
450 \\
1,840\end{array}$ & $\begin{array}{r}3,090 \\
3,000 \\
2,580 \\
5,370 \\
1,315 \\
1,620 \\
780 \\
445 \\
111 \\
480 \\
227 \\
800\end{array}$ & $\begin{array}{r}3,500 \\
2,400 \\
1,270 \\
602 \\
608 \\
905 \\
110 \\
449 \\
283 \\
560 \\
114 \\
500\end{array}$ & $\begin{array}{r}1,028 \\
1,190 \\
415 \\
1,780 \\
502 \\
387 \\
140 \\
448 \\
336 \\
112 \\
152 \\
221\end{array}$ & $\begin{array}{r}1,420 \\
432 \\
370 \\
440 \\
398 \\
538 \\
312 \\
130 \\
569 \\
90 \\
435 \\
482\end{array}$ & $\begin{array}{r}1,100 \\
705 \\
285 \\
273 \\
755 \\
224 \\
109 \\
56 \\
440 \\
99 \\
260 \\
304\end{array}$ & $\begin{array}{r}4,650 \\
1,380 \\
1,860 \\
6,000 \\
2,030 \\
2,670 \\
3,070 \\
1,340 \\
2,580 \\
865 \\
560 \\
3,200\end{array}$ & $\begin{array}{r}1,140 \\
870 \\
235 \\
2,760 \\
2,130 \\
1,360 \\
4,090 \\
2,040 \\
2,620 \\
1,030 \\
633 \\
2,540\end{array}$ & $\begin{array}{r}1,162 \\
370 \\
164 \\
201 \\
3,220 \\
326 \\
4,580 \\
830 \\
1,180 \\
634 \\
230 \\
1,000\end{array}$ & $\begin{array}{r}960 \\
450 \\
56 \\
405 \\
1,75 \\
368 \\
1,390 \\
1,560 \\
580 \\
236 \\
221 \\
210\end{array}$ \\
\hline
\end{tabular}


of 50 units of corticotrophin gel. It is noted that the mean baseline urinary 11-OHCS were raised in the subjects receiving 0.5 and $0.25 \mathrm{mg}$. of tetracosactrin. This occurred in the
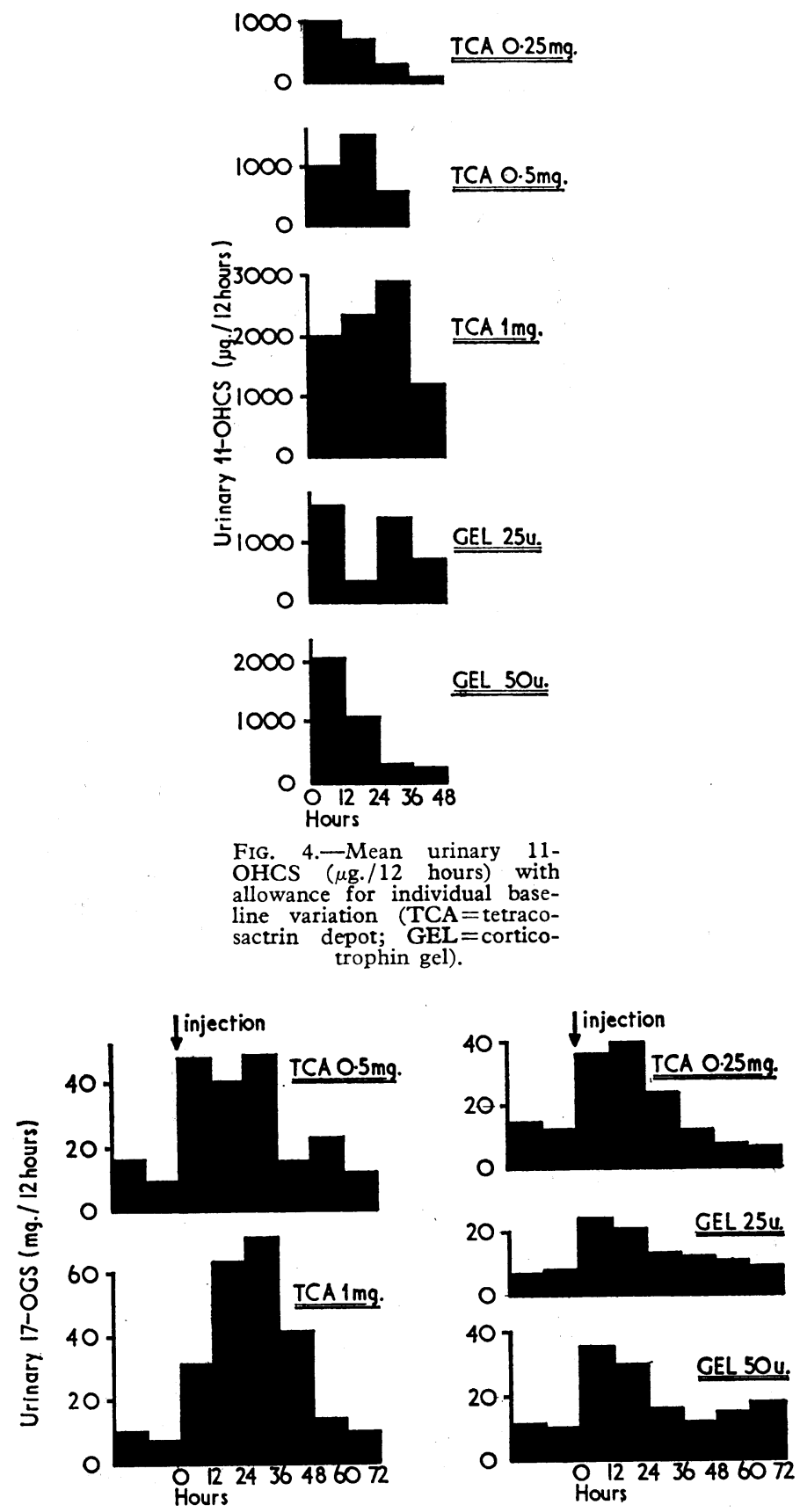

FIG. 5--Mean urinary 17-OGS (mg./12 hours) following depot tetracosactrin (TCA) at three dose levels, and corticotrophin gel (GEL) at two presence of normal values for plasma 11-OHCS. Possible reasons for these raised urinary steroid values are spurious background fluorescence due to bacteria and the undisclosed presence of certain drugs-for example, dibenzanthracene in laxatives. The normal urinary 17-OGS levels in these subjects would suggest interference with the urinary 11-OHCS determinations.

When individual baseline levels are subtracted before the urinary 11-OHCS are averaged, the resulting histogram (Fig 4) discloses the differences between the two preparations in a more obvious way, though $1 \mathrm{mg}$. of depot tetracosactrin produces an appreciably greater response than 50 units of corticotrophin gel, lasting a full 48 hours.

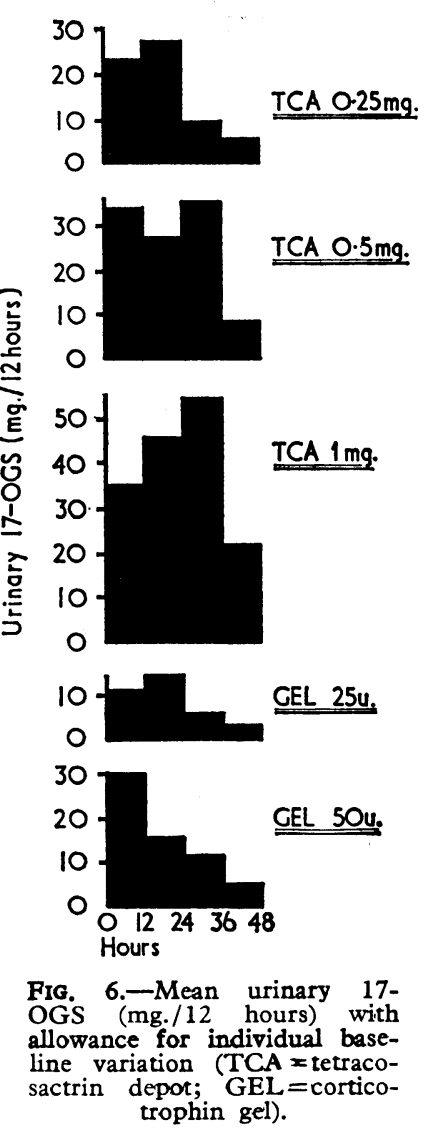

The major part of the urinary 17-OGS response following corticotrophin gel occurs within the first 24 hours (Fig. 5), the levels at 24 to 36 hours approaching the baseline after 25 or 50 units. After all three strengths of depot tetracosactrin the 24- to 36-hour levels of 17-OGS are still raised, and after $1 \mathrm{mg}$. the 36- to 48-hour level is still four times that of the baseline. Individual values for each collection are recorded in Table III.

TABLE III.-Urinary 17-OGS Expressed as mg./12 Hours for Both Collection Periods of All 6 Days in Every Patient Assessed. Corticotrophin was Administered on Day 2 and Day 5

\begin{tabular}{|c|c|c|c|c|c|c|c|c|c|c|c|c|}
\hline \multirow{2}{*}{$\begin{array}{l}\text { Case } \\
\text { No. }\end{array}$} & \multicolumn{2}{|c|}{ Day 1} & \multicolumn{2}{|c|}{ Day 2} & \multicolumn{2}{|c|}{ Day 3} & \multicolumn{2}{|c|}{ Day 4} & \multicolumn{2}{|c|}{ Day 5} & \multicolumn{2}{|c|}{ Day 6} \\
\hline & $\begin{array}{l}9 \text { a.m.- } \\
9 \text { p.m. }\end{array}$ & $\begin{array}{l}9 \text { p.m.- } \\
\text { 9. a.m. }\end{array}$ & $\begin{array}{l}9 \text { a.m.- } \\
9 \text { p.m. }\end{array}$ & $\begin{array}{l}9 \text { p.m.- } \\
9 \text { a.m. }\end{array}$ & $\begin{array}{l}9 \text { a.m.- } \\
9 \text { p.m. }\end{array}$ & $\begin{array}{l}9 \text { p.m.- } \\
9 \text { a.m. }\end{array}$ & $\begin{array}{l}9 \text { a.m.- } \\
9 \text { p.m. }\end{array}$ & $\begin{array}{l}9 \text { p.m.- } \\
9 \text { a.m. }\end{array}$ & $\begin{array}{l}9 \text { a.m.- } \\
9 \text { p.m. }\end{array}$ & $\begin{array}{l}9 \text { p.m.- } \\
9 \text { a.m. }\end{array}$ & $\begin{array}{l}9 \text { a.m.- } \\
9 \text { p.m. }\end{array}$ & $\begin{array}{l}9 \text { p.m.- } \\
9 \text { a.m. }\end{array}$ \\
\hline $\begin{array}{r}1 \\
2 \\
3 \\
4 \\
5 \\
6 \\
7 \\
8 \\
9 \\
10 \\
11 \\
12\end{array}$ & $\begin{array}{r}11.5 \\
8.5 \\
11.3 \\
21.8 \\
10.1 \\
18.5 \\
3.5 \\
10.6 \\
7.9 \\
7.1 \\
7.7 \\
14.6\end{array}$ & $\begin{array}{r}7 \cdot 3 \\
7.5 \\
11 \cdot 2 \\
5.9 \\
15 \cdot 1 \\
10 \cdot 3 \\
4.5 \\
7.9 \\
6.9 \\
6.9 \\
9 \cdot 3 \\
17.6\end{array}$ & $\begin{array}{r}32.5 \\
9.9 \\
35.7 \\
92.5 \\
53.0 \\
37.0 \\
31.0 \\
19.4 \\
19.0 \\
17.2 \\
14.7 \\
36.8\end{array}$ & $\begin{array}{l}21.8 \\
45 \cdot 0 \\
19.5 \\
75.5 \\
36 \cdot 6 \\
50.5 \\
30.5 \\
24 \cdot 2 \\
11.6 \\
10.6 \\
13.7 \\
28 \cdot 3\end{array}$ & $\begin{array}{r}38.5 \\
35.0 \\
39.0 \\
107.0 \\
14.8 \\
33.0 \\
13.1 \\
34.6 \\
11.4 \\
11.9 \\
8.9 \\
19.6\end{array}$ & $\begin{array}{r}23 \cdot 6 \\
38 \cdot 2 \\
16.4 \\
22.9 \\
10 \cdot 8 \\
12 \cdot 7 \\
7 \cdot 6 \\
9 \cdot 6 \\
9.2 \\
12.4 \\
10 \cdot 8 \\
15 \cdot 0\end{array}$ & $\begin{array}{r}16.8 \\
12.2 \\
20.9 \\
23 \cdot 1 \\
18.8 \\
14.2 \\
9 \cdot 0 \\
12.6 \\
9.4 \\
7.9 \\
10 \cdot 8 \\
23.5\end{array}$ & $\begin{array}{r}8 \cdot 5 \\
12.5 \\
7 \cdot 3 \\
13.9 \\
15 \cdot 2 \\
12 \cdot 1 \\
4.3 \\
20 \cdot 8 \\
8 \cdot 7 \\
28 \cdot 4 \\
11 \cdot 2 \\
13 \cdot 4\end{array}$ & $\begin{array}{l}27 \cdot 5 \\
19 \cdot 4 \\
14 \cdot 7 \\
78 \cdot 0 \\
48 \cdot 3 \\
43 \cdot 5 \\
53 \cdot 7 \\
32 \cdot 4 \\
19 \cdot 8 \\
41 \cdot 8 \\
18 \cdot 2 \\
41 \cdot 1\end{array}$ & $\begin{array}{r}29.5 \\
25.6 \\
12.0 \\
60.0 \\
24.5 \\
29.0 \\
103.0 \\
27.1 \\
39.2 \\
30.8 \\
47.0\end{array}$ & $\begin{array}{r}12 \cdot 0 \\
7 \cdot 6 \\
20 \cdot 8 \\
11 \cdot 2 \\
8 \cdot 5 \\
10 \cdot 4 \\
94 \cdot 0 \\
69 \cdot 0 \\
26 \cdot 2 \\
20 \cdot 5 \\
16 \cdot 5 \\
27 \cdot 5\end{array}$ & $\begin{array}{r}20.0 \\
7.5 \\
5.5 \\
18.8 \\
11.7 \\
8.5 \\
68.5 \\
38.6 \\
6.6 \\
11.3 \\
12.0 \\
14.5\end{array}$ \\
\hline
\end{tabular}


After subtraction of individual baseline levels the data on urinary 17-OGS (Fig. 6) show a similar response after $0.25 \mathrm{mg}$. of depot tetracosactrin to that after 50 units of corticotrophin gel, the higher doses of the synthetic preparation again producing a more sustained effect.

\section{Clinical Observations}

Reactions with subcutaneous administration of both preparations were not infrequent, occurring in 5 of the 12 cases following depot tetracosactrin and in 2 of 12 cases after corticotrophin gel. In every case reactions took the form of local erythema and pruritus lasting from a few hours to about two days. None was severe. In one instance corticotrophin gel was subsequently continued long-term without difficulty.

The effect of both preparations on disease manifestations did not appear to differ one from the other, apart from duration of response. There is a wide variability of dose-response among individuals to long-acting corticotrophin, so that the numbers in this series are too few to draw significant conclusions regarding the clinical dose relationship between the two preparations. Nevertheless, in every instance in which a significant clinical response to both injections occurred, that following depot tetracosactrin was sustained longer than that following corticotrophin gel.

\section{Discussion}

In terms of maximum plasma cortisol concentration Besser et al. (1967) concluded that $1 \mathrm{mg}$. of the synthetic preparation is equivalent to about 80 units of corticotrophin gel, both doses stimulating the adrenal glands maximally, but that the gel must be given twice daily and depot tetracosactrin once daily to maintain stimulation. There can be little doubt that the latter substance has a distinctly greater duration of action. In a dose of $1 \mathrm{mg}$. adrenal stimulation lasts 48 hours, implying that, in this dosage at least, injections every two days should suffice. In regard to the relative degree of adrenal stimulation, our results suggest that $0.25 \mathrm{mg}$. of depot tetracosactrin is equivalent to about 50 units of corticotrophin gel by the subcutaneous route.

It is open to question whether the prolonged action of depot tetracosactrin will prove to be an advantage in long-term corticotrophin therapy. Nichols et al. (1965) have shown that corticosteroids administered at night cause a significantly longer suppression of pituitary-adrenal response than administration earlier in the day. There is some evidence (Jasani et al., 1968) that maintenance of the diurnal rhythm of plasma corticosteroid levels is an important factor in retaining normal pituitaryadrenal response.

Clinically, local reactions to depot synthetic corticotrophin may be a problem. Within the very limited experience of this trial erythema and skin irritation were appreciably more frequent with depot tetracosactrin than with gel. No doubt local reactions would be less frequent with intramuscular injection. Such reactions are not to be confused with inactivation of the hormone by antibody formation, which is most unlikely to tetracosactrin (Felber et al., 1966).

In conclusion, it seems fair to state that depot tetracosactrin has a very real place in medical investigation and therapeutics in view of its potency and the convenience of its prolonged action. From these aspects it could replace the use of animal corticotrophin gel. The incidence of local reactions, however, may prove troublesome, and its obliterative effect on the diurnal rhythm of cortisol production is a theoretical disadvantage in long-term therapy.

Our thanks are due to Miss Rosalind Raine and Miss Mary Wesney for assistance in carrying out the plasma and urinary corticasteroid analyses. We are grateful to Ciba Ltd. for a grant to assist in this study and for supplies of depot tetracosactrin.

\section{REFERENCES}

Appleby, J. I., Gibson, G., Norymberski, J. K., and Stubbs, R. D. (1955). Biochemical fournal, $60,453$.

Besser, G. M., Butler, P. W. P., and Plumpton, F. S. (1967). British Medical fournal, 4, 391 .

Felber, J. P., Ashcroft, S. H. J., Villanueva, A., and Vannotti, A. (1966). Nature, 211, 654

Jasani, M. K., et al (1968). Annals of the Rheumatic Diseases, 27, 352. Kappeler, H., and Schwyzer, R. (1960). Experientia, 16, 415.

Kappeler H, and Schwyzer, R. (1961). Helvetica Chimica Acta, 44, 1136.

Landon, J., James, V. H. T., Cryer, R. J., Wynn, V., and Frankland, A. W. (1964). Fourmal of Clinical Endocrinology and Metabolism, $24,1206$.

Mattingly, D. (1962). Journal of Clinical Pathology, 15, 374.

Mattingly, D., Dennis, P. M., Pearson, J., and Cope, C. L. (1964). Lancet, 2, 1046.

Nelson, J. K., et al. (1968). British Medical fournal, 1, 557.

Nichols, T. Nugent, C. A., and Tyler, F. H. (1965). Fournal of Clinical Endocrinology and Metabolism, 25, 343.

\section{Preliminary Communications}

\section{Effect on Airways Resistance of Prostaglandin $\mathrm{E}_{1}$ Given by Aerosol to Healthy and Asthmatic Volunteers}

British Medical fournal, 1969, 4, 723-726

Cummary : The forced expiratory volume in one second (F.E.V..$_{1}$ ) was measured in healthy and asthmatic volunteers and the inhalation of prostaglandin $\mathbf{E}_{1}(\mathbf{P G E})$ was compared with that of isoprenaline, using metered aerosols.

In healthy volunteers $\mathrm{PGE}_{1}$, either as the free acid or the neutral triethanolamine salt, did not affect the F.E.V. ; $_{1}$ the free acid was irritant to the upper respiratory tract. In five out of six asthmatic volunteers with reversible airways obstruction, inhalation of $55 \mu \mathrm{g}$ of
PGE 1 (triethanolamine salt) produced an increase in F.E.V..$_{1}$ comparable in both degree and duration to that produced by an inhalation of $550 \mu \mathrm{g}$. of isoprenaline sulphate.

Though the triethanolamine salt was well tolerated in most of the asthmatic subjects studied, in one asthmatic subject this preparation caused coughing and there was a progressive reduction in the F.E.V..$_{1}$ associated with bronchospasm.

\section{INTRODUCTION}

The prostaglandins have been intensely studied since 1962, when the chemical structure of the first member of this group of naturally occurring fatty acids was determined (Bergström, Ryhage, Samuelsson, and Sjövall., 1962). Of their pharmaco- 